\title{
A Study of Usage of Mobile Phone by Faculty in College Premises, Lucknow
}

\author{
${ }^{1}$ Dr. Kaushiki Singh, ${ }^{2}$ Sanjeev Kumar Singh \\ ${ }^{I}$ Department of Commerce, DSMNR University, \\ ${ }^{2}$ Research Scholar, Department of Commerce, DSMNR University,
}

\begin{abstract}
As the use of mobile phones has proliferated in academic settings in recent years, new challenges are faced by institutions of higher education and their faculties. The research was carried out using questionnaires distributed to 32 faculty of various private and Government College and institution. The Schedule collected demographic information about the respondents, age, gender, cost of mobile phone, annual family income, type of college in which they are serving, usage of phone to during class and perception of faculty to allows students to pick calls during class. Research has resulted that respondent reported strong perceptions of mobile phones as a classroom distraction in teaching and learning environment.
\end{abstract}

Keywords: Age, Perception, Cost of mobile phone, type of college

\section{Introduction}

India's mobile phone subscriber base crested the 1 billion users mark, as per data released recently by the country's telecom regulator. The story has been one of striking rise in penetration which got millions of Indians talking to each other and putting their devices to a variety of innovative uses. The need for people to connect with others frequently is apparent in our society. People use mobile phones everywhere and every time, to call and text friends, surf the web, visit social sites and attach themselves to their communication devices at all times. As the use of mobile phones has proliferated in academic settings in recent years, new challenges are faced by institutions of higher education and their faculties. Students and their devices have become virtually inseparable. The variance in students ability to focus and engage in the actual task at hand is disconcerting. More middle, secondary-school teachers and Faculty in college are using mobiles phone during class. Traditionally, the learning environment used to be quite and pleasant. The classroom discipline was one of the most important aspects in teaching and learning environment and considered as a basic requirement. Mobile phones have been observed to be a big disturbance in the class room environment. Any disturbance due to use of mobile phone inside a classroom like answering phone calls or sending test messages is unacceptable thing. If a mobile phone rings during a lecture it not only disrupts the learning of that student, but diverts other students' mind from the lecture and breaks the tempo of the teacher. Even if the mobile phone is put on a silent mode still students have been found to use it for messaging and doing other applications. Researcher has tried to draw the relationship between the variables mentioned in the objective with the help of testing hypothesis.

\section{Review Of Literature}

Alka Shrivastava and Manish Shrivastava (2014): Researcher studied in his paper "Classroom Distraction Due to Mobile Phones Usage by Students: College Teachers' Perceptions" that Smart phones and other handheld devices are largely used by the students. This paper presents the result of a study conducted on teachers of various institutes of higher education in Oman. Total 32 teachers from both the public and private colleges and universities were responded the questionnaire. The results of the study show that participants reported strong perceptions of mobile phones as a classroom distraction in teaching and learning environment and students' misconduct. It has been strongly confirmed that mobile phones are misused and is potential source of stress among faculty and lack of concentration among students. Research indicates that increasing use of mobile phones by the students in the classroom is a big interruption.

Muhammad,J., Muhammad,A.M., and Gujjar,A.A. (2011) : Researcher studied in his paper "Mobile Phone Culture and its Psychological Impacts on Students' Learning at the University Level" that Mobile phone has affected almost every field of life but its effects on students" learning especially at university level are deep and in multidimensional and multifarious. Our youngsters have been completely mesmerized and hypnotized by this magical device. Now it has become an essential part of modern life and is playing a vital role in decreasing distance and increasing communication among people. The study was conducted in order to determine the effects of mobile phone on the performance of students at university level. Most of the students claimed that they can contact with their teachers and class mates to discuss the educational matters. They also utilize the mobile phone to share the useful information with their class fellows, to consult dictionary and thesaurus for 
educational purposes. On contrary to this they are agreed that the mobile phone is wasting the studentse precious time and money. Moreover it has increased the rate of telling lie among students.

Emeka Ezemenaka (2013): Researcher studied in his paper "The usage and impact of Internet enabled phones on academic concentration among students of tertiary institutions: A study at the University of Ibadan, Nigeria" that study looks into the usage and perceived effect implications internet enabled phones have on the academic performance of the tertiary students using University of Ibadan students in Nigeria as a case study. The study was carried out in order to understand and bring to fore if the students' academic performance is affected due to the time channelled to the phone during class hours which has a general perception as a medium of distractions to students. The analysis of the students' perception showed that the internet enabled phone usage does not affect the academic performance of the students but distractions by the usage of phone were notably admitted.

Kahari, L. (2013) : Researcher studied in his paper " The effects of Cell phone use on the study habits of University of Zimbabwe First Year Faculty of Arts students" that to examine the effects of cell phone use on the study habits of University of Zimbabwe 1st year Faculty of Arts students. The results showed significant gender differences in several aspects of cell phone use and revealed that cell phone use has negative and positive effects on the study habits of university students depending on usage patterns. The study concluded that despite the challenges faced by students ,cell phones unlike other educational innovations are firmly rooted in the society in which education and institutions are part of and ignoring the use or applications of this technology would be ill-advised.

\section{Objective}

The main objective is to study the relationship among the variable such as age of the faculty, gender of the faculty, cost of mobile phone, annual family income, type of college in which faculty is serving, usage of phone during class and perception of faculty to allows students to pick calls during class.

\section{HYPOTHESIS:}

H0: There is no relationship among the type of college and age of faculty.

H0: There is no relationship among the gender and approximate cost of mobile set of faculty.

H0: There is no relationship among type of college and perception that class get disturbed when mobile phone is being used by faculty during class.

H0: There is no relationship among type of college and perception that class get disturbed when mobile phone is being used by faculty during class.

\section{Methodology}

The methods that are used in collecting and analyzing data from the field includes schedule and research approach respectively. A study was conducted in Lucknow, Uttar Pradesh. Total 32 teachers from both the public and private colleges and universities were responded to the schedule are randomly selected and their opinion and perception was recorded. The study is analytical in nature, and it is based on the Primary data collected from the faculty of various government and private institution. Schedule is used as data gathering instrument.

\section{Findings}

1. Analysis reveals that if the age is less than 31 years than usage of mobile phone by faculty member was more than 4hours in a day. However, as the age was 31 or more, then usage was mobile phone decrease and restricted upto $3 \mathrm{hrs}$.

2. Faculty having average family income amounting Rs. 920833 would prefer prepaid connection; however those having average family income amounting Rs. 1430000 prefer post-paid connection. Hence it can be concluded that those average family income is less than Rs. 920833 are more sensitive to their income and spend as per requirement and prefer prepaid connection whereas others would prefer to spend and then pay.

3. Analysing reveals that when average age of faculty was less than 30.57 years, they allow the students to receive calls during the classes. when average age increase i.e. 30.69 years they rarely allow the student to receive call and average age goes beyond 32 years, they never allowed to attend the call during the classes. Hence it can be concluded that there is inverse relationship between age of faculty and allow the students to receive the calls.

4. After analysing data, it reveals that when average age of faculty was 28 years or less, sometime they receive calls during the classes. when average age increase i.e. 30.80 years they rarely receive call and average age goes beyond 31.5 years, they never receive the call during the classes. Hence it can be concluded that there is inverse relationship between age of faculty and receiving the calls during the class hours. 
5. $66.7 \%$ respondent among males has perception that mobile phone are very important for accessing the social networking sites where as $33.3 \%$ has perception that its not required at all. $15 \%$ respondent among females has perception that mobile phone are very important for accessing the social networking sites whereas $30.0 \%$ has perception that it is important, $45 \%$ has perception that its useful and $10 \%$ feels that its not required at all.

Among the total respondent $40 \%$ male and $60 \%$ female has the perception that it is very important to access social networking sites. Among the total respondent, $100 \%$ female consider that it is important and its useful to access social networking sites. However, among the total respondent $33.3 \%$ male and $66.7 \%$ female has the perception that its not required at all.

Hence it can be concluded that as the female perception towards accessing the social networking site by mobile phone is useful and important as compare to male faculty.

6. Analysis reveals that those who are employed in private college carry mobile of an average cost amounting Rs. 24465 while those are employed in Government College carry mobile of an average cost amounting Rs.14177. Hence it is concluded that faculty in private college spend more on mobile set as compare to government college.

7. After analysing the data it reveals that those who are employed in private college has an average bill amounting Rs. 704 while those are employed in Government College has an average bill amounting Rs. 917. Hence it is concluded that faculty in private college spend more on mobile set and less on mobile bill and for faculty of Government College is vice versa.

8. $9.1 \%$ respondent among private college are using the phone for $0-12$ month where as $4.5 \%$ are using for 12-24 month, $4.5 \%$ are using for 24-60 month, $72.7 \%$ are using for more than 60 month and $9.1 \%$ are fall in other category. 33.3\% respondent among government college are using the phone for 0-12 month where as $11.1 \%$ are using for $12-24$ month, $11.1 \%$ are using for $24-60$ month and $44.4 \%$ are using for more than 60 month. Among the total respondent $40 \%$ from private college and $60 \%$ government college are using the phone for $0-12$ month. similarly among the total respondent $50 \%$ from private college and $50 \%$ government college are using the phone for 12-24 month and 24-60 months. Among the total respondent from private college $80 \%$ and $20 \%$ government college are using the phone for more than 60 month.

9. We do not reject the hypothesis as there is no relationship exist among the type of college and age of faculty as there significance value (Sign. Value $=0.902$ ) is more than 0.05 .

10. We do not reject the hypothesis as there is no relationship exists among gender and approximate cost of mobile set of faculty as there significance value (Sign. Value $=0.935$ ) is more than 0.05 .

11. We do not reject the hypothesis as there is no relationship exists among gender and perception that class get disturbed when mobile phone is being used by faculty during class as there significance value (Sign. Value $=0.171)$ is more than 0.05 .

12. We do not reject the hypothesis as there is no relationship exists among type of college and perception that class get disturbed when mobile phone is being used by faculty during class as their significance value $($ Sign. Value $=0.056)$ is more than 0.05 .

\section{Conclusion}

On the basis of finding we can conclude that there is no relation of Gender and type of college with the perception that class get disturbed when mobile phone is being used by faculty during class. Further usage of phone in terms of no. of hours is inversely related to age. The results of the study shows that respondent reported strong perceptions of mobile phones as a classroom distraction in teaching and learning environment.It reveals that faculty are more concerned with the study of students. They do not use their own mobile and not allow the student to use their phone during the class irrespective of their age and type of college where they are serving.

\section{References}

[1] Shrivastava, A., and Shrivastava, M. 2014. Classroom Distraction Due to Mobile Phones Usage by Students: College Teachers Perceptions. International Journal of Computer and Information Technology, 3(3), 638-642.

[2] Muhammad, J., Muhammad, A.M., and Gujjar, A. A. 2011. Mobile Phone Culture and its Psychological Impacts on Students Learning at the University Level. LANGUAGE IN INDIA, 11(2), 415-422.

[3] Ezemenaka, E. 2013. The usage and impact of Internet enabled phones on academic concentration among students of tertiary institutions: A study at the University of Ibadan, Nigeria. International Journal of Education and Development using Information and Communication Technology, 9(3), 162-173.

[4] Kahari, L. 2013. The effects of Cell phone use on the study habits of University of Zimbabwe First Year Faculty of Arts students International Journal of Education and Research, 1, 1-10. 